Анатолій Поповський

Доктор філологічних наук, професор Дніпропетровський державний університет внутрішніх справ м. Дніпро

\title{
РУСИФІКАЦІЯ - СУРЖИК - ВУЛЬГАРИЗАЦІЯ В КОМУНІКАТИВНОМУ ДИСКУРСІ УКРАЇНСЬКОГО ПОЛІКУЛЬТУРНОГО ПРОСТОРУ
}

\section{Нації вмирають не від інфаркту, У них спочатку мову відбирають. \\ Ліна Костенко}

Питання русифікації іншомовних народів Російської імперії слід розглядати в зв'язку з розширенням іiї територіальних меж шляхом завоюванням чужих земель Московією від часу виникнення й до нинішніх днів. Відтоді ретельно культивується примус «російського громадянства», як це спостерігаємо нині в окупованому Криму і Донбасі. Відтоді ідеологи Москви на всіх етапах історичного розвитку імперії (царської і комуністичної Росії) вели послідовну роботу щодо заборони мови, культурних традицій, нищення історичних пам'яток українського народу. Жодна мова в світовій історії не зазнала таких нищівних утисків від сусідів «братьевсловян», як українська. Як свідчить академік АН ВШ України Ніна Вірченко на сьогодні виявлено всього офіційних і неофіційних документів про заборону української мови $31626-2001$ pp. - 114 [2]. Варто лише порівняти зухвалий цинізм послідовників валуєвщини царської Росії і «комуністичний демократизм» ідеологів марксизму-ленінізму бодай 3 витягу секретного документу, складеного полтавським губернатором Багговутом і надісланого Міністру внутрішніх справ Росії 4лютого 1914 року: «Доношу Вашему Высокопревосходительству, что украинское движение, в основу которого положена идея образования автономной Украины под скипетром Габсбургской династии, принимает за последнее время широкие размеры....Несмотря на категорическое требование инспекторов вести обучение только на русском языке, учителя уклоняются от этого при всяком удобном случае и приводят постоянно одну и ту же отговорку, заключающуюся в том, что язык малорусский есть их родной язык, что только на этом наречии дети 
быстро усваивают предмет преподавания и что нет никакой беды в том, что параллельно с русским языком даются объяснения на малорусском, ибо поступающие в школу дети у себя дома все-таки говорят по-малорусски...и что движение это становится за последнее время бесспорно опасным для России, то я полагаю необходимым бороться с украинским движением следующими мерами:

1. Привлекать на должность учителей земских начальных школ по возможности только одних великороссов.

2. Назначать на должность инспекторов народных училищ людей деятельных, энергичных, твердых и исключительно великорусов. Таковыми же, конечно, должны быть и директоры народных училищ.

3. Всякого учителя, проявляющего склонность к украинскому движению, немедленно устранять.

4. Поставить правильно обучение истории России в школе и строжайше вменить в обязанность учителям - внедрять в молодежь понятие о единой, неделимой России, поясняя смысл слова «украина» то есть «окраина» Государства в былые времена.

5. Установить обязательные экскурсии учащихся всех учебных заведений в возможно большом количестве - Москву, Нижний Новгород и другие исторические местности России, ибо малорусы имеют об памятниках этих местностей весьма скудные сведения, вернее никаких. Экскурсии ныне производятся в Киев, а об Москве и речи не бывает.

6. Обратить особливое внимание на семинарии, на учебновоспитательную часть в этих учебных заведениях. Ставить во главе их ректоров исключительно великорусов, удалить немедленно всех слабых и бездеятельных ректоров. Учащий персонал должен быть только из великорусов. За семинарии надо взяться как следует и искоренять гнездящийся в них дух и дать им должное направление.

7. Необходимо субсидировать некоторые газеты, издающиеся в Киеве, Харькове, Полтаве и Екатеринославе с целью борьбы, путем печати, с украинским движением. Основания борьбы должны быть следующие: 
a) доказательство кровной родственной связи народностей великорусской и малороссийской; признание общего корня этих наречий и полонизации малорусского языка в прежние времена;

б) разъяснение, что «украина» означает «окраину» и что такие окраины до присоединения малороссиии к России были и у Польши и у России. Необходимо правдиво освещать историю заселения Южно-Русских степей и всей вообще «окраины» Государства, поясняя, что никогда никакого украинского народа не было;

в) возможно частое появление в субсидированных газетах статей о необходимости общегосудаственного языка, каковым только и является великороссийское наречие, о богатстве русского языка, обширности и богатстве его литературы и т. д., о роли современного малорусского языка как простонародного и не имеющего литературы и будущности [4, с. 49-52].

Ще жорстокішими були заходи щодо боротьби проти «національного ухилу» українських патріотів у роки радянської влади, як-от:

1932 - 1933 pp. Сплановано і здійснено за мовчазною згодою «світового співтовариства» акцію ліквідації українського народу. Свідоме знищення більшовицьким режимом українських селян організацією голодомору. Централізоване переселення росіян у вимерлі села України. В Україні, яка володіє 40\% світового чорнозему, умертвлено голодом до 10 мільйонів носіїв української мови, і саме селян, щоб зберегти зрусифіковане міське населення.

1937 р., листопад. На відзначення 20-річчя приходу комуністів до влади на Соловках було розстріляно понад тисячу діячів української культури.

1951 р. Викриття газетою «Правда» - центральним органом ЦК ВКП(б), «націоналістичних ухилів» в українській літературі (вірш В.Сосюри «Любіть Україну», лібрето опери «Богдан Хмельницький» і т.д.). Студенти Харківського університету відмовилися складати іспити російською мовою. Тоді 800 з них було репресовано, а 33 студентів на закритому засіданні суду було засуджено до смертної кари! І розстріляно.

1958 р. Постанова Пленуму ЦК КПРС про перехід частини українських шкіл на російську мову викладання. Відповідну постанову прийняла і Верховна Рада УРСР [2]. 
На жаль, світова спільнота до цих пір не внесла такого цинічного явища до світових рекордів книги Гіннеса.

У суверенній Україні про загрозу мовного засмічування іноземними запозиченнями, деформацією українських прізвищ та продукування своїх мовних покручів постійно застерігають провідні мовознавці - П.Гриценко, Я.Винницький-Радевич, Л.Масенко, О.Пономарів, О.Сербенська, I. Ющук; науковці - Н.Вірченко, С. Свідлов В.Явір; діячі культури - В.Карпенко, В.Крищенко, Т. Компаніченко, А.Матвієнко, О.Скрипка, О. Романчук; письменники - Л.Ніцой, С.Лірник В.Яворівський; народний депутат України Олег Медуниця, Голова Донецької Облдержадміністрації П.Жебрівський, Голова Всеукраїнського Товариства політичних в'язнів i репресованих О.Сокульська; блогер О.Аронець; педагоги середніх і вищих навчальних закладів та ін. Але реакція на це державних мужів лишилася байдужою, як у байці І.Крилова «Кіт і кухар» реакція Кота, який поцупив кусень м'яса, на повчання господаря так: «Кот Васька слушает да ест». Більше того: маємо нарешті новий Закон про освіту, а ганебний закон Ківалова-Колісніченка про надання державного статусу російській мові, ухвалений Верховною Радою України, так і не скасовано.

Проте методи асиміляції численних етносів колишнього СРСР ретельно удосконалюються ідеологами Кремля та їхніми сучасними поплічниками-пятиколонниками в українському суспільстві. Така собі розважальна штепсельо-тарапуньківщина, виплекана радянськими діячами культури міцно вкоренилася в практиці українських засобів масової інформації - телебаченні, радіо, пресі. Такий мовний паралелізм - благодатний грунт для суржика. Більше того, працівники ЗМІ замість того, щоб пропагувати висококультурні зразки українського літературного мовлення, здебільшого самі порушують мовно-літературні норми української мови, а запрошені для виступу представники різнофахових галузей тим паче. Чого варті тільки мовні перлиночки в передачі «круто ведучої» Українського радіо Марини Куликової 3 директором проекту «Інкубатор» Євгенією Клепою 26.09.2017 р.: «Не всі слухачі наші такі круті....у кого виникла крута ідея,...громадянська позиція - це круто, модно, ...а зараз розкажіть про круті проекти,.. це дуже крута практика»,...у мене є крута ідея, або в передачі «На відстані кліпу» 4.06.2017 р.: «Цифрова криптовалюта - це дуже круто...Ну 
да. Це дуже круто!.. Слухачі зрозуміли, що це круто... Це крута фішка bitkojn...»; «...я сідаю й не працюю, а кайфую (Укр.радіо, 16.11.2017). Продукує цю лексичну одиницю також і періодика: Стоїть сцена, грає місцева група, або лунає вальс, під який місцеві дідусі і бабусі танцюють. Причому, дуже круто, бо там (в північній Італії. - А.П), всі пенсіонери ходять на танці (Українське слово, № 42, 18-24. 10, 2017, с. 11). На Донбасі є дві специфічні групи населення, які можна умовно назвати «ватниками» $\mathrm{i}$ «раками» (або «малиновими піджаками», був такий «спецодяг» бізнесменівнуворишів, усіляких крутих, кримінальних і напівкримінальних елементів у 90-ті роки минулого століття). [Шлях перемоги, № 38, 17 вересня 2014, с. 4]. Складається враження, що деякі працівники ЗМІ мають хронічну недугу на на модні словечка шоу, круто, кльово, супер, в якості, креативно, кароче та ін., засмічуючи і витісняючи 3 ужитку наявні елегантні мовні ресурси української мови. I таке крутослів'я легко засвоюється слухачами, від чого й занепадає рівень культури мовлення нашого суспільства, бо відсутній належний контроль за чистотою ефірного мовлення. Ще показовішим $\epsilon$ усне мовлення керівних працівників медицини: «...апарат іскуственної нирки,..общий аналіз крові,..щоб подивитися сосуди,... ілі подагра, ілі нефріт,... зачастую прекращаються болі (Укр. радіо, 25.09.2017) тощо; спорту, де також не все гаразд 3 українською мовою як серед спортсменів, так i їхніх тренерів, наприклад: генеральний тренер 3 плавання Андрій Глазков утнув таке: «...у плаванні досягають успіху діти більшого віку» (Укр. радіо, 27.10.2017). «Далі Кличко звернувся до фанатів, назвавши їх крутими. Цікаво, у чому їхня «крутизна». Адже перед боєм ледве не всі вболівальники зустріли Володимира принизливим свистом [3, с. 8]. Навіть школярам радіоведучі рубрики «Школяда» Андрій Дубич i Катерина Зайцева нав'язливо радять «мандрувати дуже круто!» (Укр. радіо, 30.12.2016) і слухати «Дошку приколь-коль-кольних новин». Не відстають у цьому плані й працівники української реклами в інтернеті, на білбордах: «Крутий жіночий парфум зі знижкою. Вже кінець розпродажі» (26.12.2016). Безтямно калькуються 3 російської мови слова й словосполучення, як-от: «...чи не розпахуються кургани» (Обл. радіо, м. Дніпро, 26.11.2017); «приглашать в качестве почетных гостей» - «...запрошували в якості почесних гостей» (Укр. радіо, 06.01.2017) замість « запрошували як 
почесних гостей». «Якщо навіть особисто Олександр Щербаков і не підписував смертні вироки під час репресій ( у що теж важко повірити), то, безумовно, так чи інакше був дотичним до них в якості партсекретаря (зам. як партсекретар) та вправного представника сталінської машини-м'ясорубки, яка перемолола мільйони українців $[1,3] ;$...в якості прикладу (як приклад / для прикладу) він назвав графік реформ (Укр. радіо, 29.01.2011), ... прийнято в якості повноправного члена ЮНЕСКО (Укр. радіо, $15.10 .2017)$, ... інститут зберегти в якості освітнього центру (Дніпропетровське обласне радіо, 17.10.2017,) або ось таке оголошення в трамваї першого маршруту м. Дніпро в день святкування працівників побуту «День Быта»: ... «запрошуємо відвідати наші вкуснощі» і т.п. А вчена «братія мовчить собі, витріщивши очі, може так і треба?!» А тим часом мовленнєва пошесть на блотні й модні словечка та іноземні запозичення розповзаються серед різновікового населення, витісняючи усталені літературні норми питомої лексики. То ж і не дивно, що через байдужість до інтелектуального рівня комунікативного дискурсу в полікультурному просторі мовленнєвих новацій сучасних ЗМІ і побутовому мовленні набули поширення такі лексичні одиниці північного сусіда, як блін, кароче, тіпа, пахан, чувак, чувіха, тьолка, казьол, женщина, мужчина, мент, ментовка, обалденная риба, кльово, прикольно, предки, давай, чефір, а також іноземні запозичення: шоу, супер, інтерактивно, креативно, плейов, моніторити, драйвово, кайф, кайфувати, хіти і т.п., наприклад, у контексті: Макс Прудеус (радіо «Культура» 05.07.2017) коментує твори молодих музикантів: «Прикольні емоції! Крута акустика!»...Марина Куликова в спілкуванні з Дмитром Сусловим (рубрика «На відстані кліпу»): «Особливо це круто!.. То справді оце круто! Класна штука! В-а-а-а-у-у-у» (Укр. радіо, 08.05.2017). «...як зазначила креативний продюсер Сінкевич, 10 років роботи над книгою про ріку Дністер - це круто!» (Укр. радіо, 29.09.2017). ...шукаєм творчих, креативних людей (Укр. радіо, 09.10.2017). ...виявляють креативні і творчі підходи до освіти (Укр. радіо, 20.01.2018)) ...креативний талант (Укр. радіо, 16.10.2017). «Люди, яких я зустрів в Україні, усі були високоосвічені і 3 гарними манерами», - каже креативний директор рекламного агентства Хідео із Японії (Українське слово, № 42, 18-24.10.2017, с. 11). ...креативні 
завдання для дітей (Укр. радіо, 22.10.2017). Відверто, оперативно, драйвово! (Укр. радіо, 16.10.2017). ...вперше батл! Неймовірне видовище, шоу! (Укр. радіо, 10.11.2017). А ось ще зразок мовлення 3 ефіропроекту «Війна і мир» 3 участю журналіста Майкла Щура i ведучих Юрія Макарова та Свгена Степаненка (Укр. радіо, 11.11.2017 р.: «Я вірю цьому хлопцю. Він крутий... Наш глядач не такий просунутий, кльовий...Він скаже, блін, я бачу: цей краде і на крові наших хлопців купує джипи...». І такої словозливної крутизни та інших мовних покручів, граматичних, стилістичних огріхів та матюччя можна наслухатися достатньо, уважно прислухаючись до радіо і телепередач, буденних розмов у громадському транспорті, до розмов прохожого люду.

Русифікація українського населення за часів московії та радянщини впродовж трьох $з$ половиною століть зробила свою чорну справу. І хоч Україна вийшла зі складу російської імперії ще 26 років тому, але імперія не вийшла зі складу України. Вона залишила тут свій «язик», а також церкву, театри, школи, ЗМI, топоніміку й агресивну п’яту колону «руського мира», окупувала Крим, Донеччину і всупереч усім міжнародним угодам веде війну на сході України.

Внаслідок тривалої асиміляції в свідомості певних прошарків сучасного покоління українців міцно вкорінився суржик, всюди сущий матюк як у живому народному мовленні, так і в 3МI, художній i науковій літературі. А відтак мусимо ж нарешті реагувати на застереження, висловлене видатним українським мовознавцем XIX ст. П.Житецьким про те, що «русифікація збільшить кількість розумових калік».

Апатія державотворчої еліти до усталених віками етичних літературних норм усного і писемного мовлення сприяє тільки деградації української культури. I це стосується не тільки не тільки української мови, а й сучасної української пісні, музичних творів, кіно, радіо, телебачення.

Постає нагальна потреба викорінення цього негативного явища таким охоронно-правовим статусом, який би ретельно оберігав чистоту мови і мав правові санкції захищати іiі від будь-яких посягань, як це спостерігаємо в країнах Прибалтики, Польщі, Угорщини, Франції,Фінляндіï, Чехії. 


\section{Література}

1.Бондаренко Станіслав. Коли буде вулиця Марченка / Станіслав Бондаренко. - Літературна Україна, 2008, 30 жовтня.

2.Вірченко Ніна. Документи про заборону української мови / Ніна Вірченко. - http://h.ua/story/41654/\#ixzz45m5TDEZC.

3.Жибак Григорій. Прикре фіаско в Англії / Григорій Жибак. - Шлях перемоги, № 18, 2017, 3 травня.

4.Явір Валентина. Мова і нація: методичні рекомендації із спецкурсу для студентів-філологів / Валентина Явір. - Кривий Ріг, 1995. - 54 c. 